\title{
Paired Related Homeobox Protein 1 is a Regulator of Stemness in Adult Neural Stem/Progenitor Cells
}

\author{
Koji Shimozaki, ${ }^{1}$ Gregory D. Clemenson Jr, ${ }^{2}$ and Fred H. Gage ${ }^{2}$ \\ ${ }^{1}$ Division of Functional Genomics, Center for Frontier Life Science, Nagasaki University, Nagasaki 852-8102, Japan and ${ }^{2}$ Laboratory of Genetics, The Salk \\ Institute for Biological Studies, La Jolla, California 92037
}

\begin{abstract}
Newborn neurons are generated from neural stem cells (NSCs) in two major niches of the adult brain. Maintenance of self-renewal and multipotency of adult NSCs is controlled by multiple transcription factor networks. We show here that paired related homeobox protein Prx1 (MHox1/Prrx1) plays an important role in the maintenance of adult NSCs. Prx1 works with the transcription factor Sox2 as a coactivator, and depletion of Prx1 in cultured adult mouse NSCs reduces their self-renewal. In addition, we find that Prx1 protein is expressed in Sox $2^{+} / \mathrm{GFAP}^{+} / \mathrm{Nestin}^{+}$astrocytes in the germinal regions of the adult mouse forebrain. The continuous expression of Prx 1 in proliferating adult mouse hippocampal stem/progenitor cells in vivo leads to the generation of radial/horizontal-shaped astrocyte progenitor- and oligodendrocyte progenitor-like cells with no newborn neurons in the neurogenic niche. These data suggest that Prx1 plays an important role as a key switch for neural cell lineage determination and the maintenance of the self-renewal of adult NSCs at several stages in the adult brain.
\end{abstract}

\section{Introduction}

Adult neurogenesis in the brain is an important process that continues throughout life. Self-renewing adult neural stem cells (NSCs) drive neurogenesis in the subventricular zone (SVZ) of the lateral ventricle and the subgranular zone (SGZ) of the hippocampal dentate gyrus (DG) (Gage, 2000; Alvarez-Buylla and $\mathrm{Lim}, 2004)$. NSCs in the SVZ are Sox $2^{+} / \mathrm{GFAP}^{+} / \mathrm{Nestin}^{+}$ astrocyte-like cells that produce progenitor cells that differentiate into neuroblast cells and then mature interneurons in the olfactory bulb (Doetsch et al., 1997, 1999). NSCs in the SGZ are radial/ horizontal shaped Sox ${ }^{+} / \mathrm{GFAP}^{+} / \mathrm{Nestin}^{+}$astrocyte-like cells that produce neuronal progenitor cells. These cells generate proliferating migratory neuroblast cells that ultimately differentiate into neurons (Kempermann et al., 2004; Steiner et al., 2006; Lugert et al., 2010).

Sox2 is a transcription factor required for the maintenance of NSCs in the CNS (Ferri et al., 2004; Suh et al., 2007). Sox2 is a member of the SRY-related box gene family, which encodes tran-

\footnotetext{
Received Sept. 26, 2012; revised Dec. 21, 2012; accepted Jan. 12, 2013.

Author contributions: K.S. and F.H.G. designed research; K.S. and G.D.C. performed research; K.S. and G.D.C. contributed unpublished reagents/analytic tools; K.S. analyzed data; K.S. and F.H.G. wrote the paper.

This work is supported by the James S. McDonnell Foundation, Mather's Foundation, National Institute of Mental Health, Ellison Foundation, and JPB Foundation to F.H. Gage and a Grant-in-Aid from the Japan Society for the Promotion of Science, a Grant-in-Aid of Alumni association of Nagasaki University School of Medicine, a Grant-inAid-for Young Scientists (B), and the Ministry of Education, Culture, Sports, Science, and Technology of Japan. We thank S. Christenson for secretarial assistance and L. Moore, B. Miller, K. McIntyre, D. Sepp, E. Mejia, R. Keithley, and J. Jepsen for technical help as well as J. Ray, S. Jessberger, T. Sawai, and A. Tashiro for technical advice. We also thank M. Kern for Prx1 antibodies and I. Verma for CAG-IRES-GFP.

The authors declare no competing financial interests.

Correspondence should be addressed to either of the following: Koji Shimozaki, Division of Functional Genomics, Center for Frontier Life Science, Nagasaki University, Nagasaki 852-8102, Japan, E-mail: shimozak@nagasakiu.ac.jp; or Fred H. Gage, Laboratory of Genetics, The Salk Institute for Biological Studies, La Jolla, CA 92037, E-mail: gage@salk.edu.

DOI:10.1523/JNEUROSCI.4586-12.2013

Copyright $\odot 2013$ the authors $\quad 0270-6474 / 13 / 334066-10 \$ 15.00 / 0$
}

scription factors with a high-mobility group DNA-binding (HMG) domain (Uchikawa et al., 1999), which binds partners that cooperate in its transcriptional regulatory functions (Kondoh and Kamachi, 2010). Each Sox2-partner pair targets specific regulatory genes that affect the differentiation of particular cell lineages (Kondoh and Kamachi, 2010; Miyagi et al., 2009; Pevny and Nicolis, 2010), such as the Sox2-Oct3/4 pairing in embryonic stem cells (Niwa, 2001) and the Sox2-Pax6 pairing in the primordium of the visual system (Kamachi et al., 2001; Inoue et al., 2007). Identification of new partners for Sox 2 is, therefore, of great importance for elucidating adult neurogenesis. Using a yeast two-hybrid screening system, we identified paired type homeobox transcription factor 1, as a novel Sox2-pair protein in adult NSCs.

Paired-type homeobox transcription factors have important functions in the regulation of developmental morphogenetic processes across species (Scott et al., 1989; Gehring et al., 1994). There are two subclasses: paired-type homeodomain and paired domain containing factors such as Pax family proteins and paired-type homeodomain-only containing factors (Galliot et al., 1999; Meijlink et al., 1999). Prx1 (also known as MHox, k2, Pmx, and Prrx1) is in the latter category and contains a paired-type DNA-binding homeodomain but lacks a second DNA-binding domain present in other paired-related homeoproteins (Cserjesi et al., 1992; Kern et al., 1992, 1994; Norris et al., 2000). Prx1 is essential for development as mice with a disrupted Prxl gene show perinatal death with craniofacial and limb malformations (Martin et al., 1995). Prx1 is expressed in a number of undifferentiated mesenchymal cells in mouse embryos and adults (Opstelten et al., 1991; Nohno et al., 1993; Kuratani et al., 1994; Leussink et al., 1995); however, the role of Prx1 in adult NSCs is currently unknown.

In this study, we show that Prxl is expressed exclusively in Sox $2^{+} / \mathrm{GFAP}^{+} / \mathrm{Nestin}^{+}$astrocytes in the adult SGZ and SVZ in 
mice. Additionally, we provide evidence that $\operatorname{Prx} 1$ and Sox 2 as a cofactor are important in the self-renewal of adult NSCs and control the differentiation of hippocampal stem/progenitor cells in the adult brain.

\section{Materials and Methods}

Yeast two-hybrid screening. For a bait plasmid, pGBK-Sox2HMG (rat Sox2: 39-117 aa) was transformed into the AH109 yeast strain together with a cDNA library (generated from adult neural stem/progenitor cells from an adult mouse whole brain) fused to a Gal4 activation domain. Library screening was performed using $\beta$-galactosidase ( $\beta$-gal) reporters following the matchmaker Two-Hybrid System Protocol (Clontech Laboratories). Clones interacting with Sox 2 were identified by growth on selective medium in the presence of $25 \mathrm{~mm} 3$-aminotriazole and confirmed by assaying for $\beta$-gal activity.

Immunoprecipitation. Western blot analysis was performed as described previously (Shimozaki et al., 2012). Briefly, 293T cells transfected with Myc-tagged Sox 2 and/or Flag-tagged Prxla transgenes were lysed by sonication in NP-40 lysis buffer $(0.5 \%$ Nonidet P- $40,10 \mathrm{~mm}$ Tris- $\mathrm{HCl}$, pH 7.4, $150 \mathrm{~mm} \mathrm{NaCl}$, protease inhibitor mixture; Pierce). Lysates were immunoprecipitated with the indicated antibodies and subjected to SDSPAGE, followed by Western blot analysis. Mouse anti-Flag (Sigma) or anti-Myc (9E10; Millipore) antibodies were used and secondary antibodies conjugated to horseradish peroxidase were obtained from GE Healthcare. Signals were detected with the ECL detection system (GE Healthcare). To examine the interaction of endogenous Sox2 with Prx1, adult mouse NSCs transfected with pEF-Flag (Mock) or pEF-Flag-Prx1 (Flag-Prx1) were harvested and lysed with a Nuclear Complex Co-IP Kit (Active Motif). The nuclear extracts were immunoprecipitated with antiFlag antibody (Sigma) and subjected to Western blotting with rabbit anti-Sox2 (Cell Signaling Technology) according to the manufacturer's instructions.

Adult neural stem/progenitor cell cultures and 5-bromodeoxyuridine treatment. The stem/progenitor cells from the forebrains of adult female rats or mice were prepared as described previously (Ray and Gage, 2006). Rat adult hippocampus stem/progenitor cells (AHPs) were cultured in DMEM/F12 medium containing N2 supplement plus FGF-2 (20 ng/ml) on poly-L-ornithine/laminin-coated dishes. NSCs from mouse whole forebrains were cultured in DMEM/F12 medium with N2 supplement plus FGF-2 (20 ng/ml), EGF (20 ng/ml), and heparin $(5 \mu \mathrm{g} / \mathrm{ml})$. For gene-depletion analysis, adult NSCs were transfected by the Nucleofection system (Amaxa) with vectors that express scramble sequence of short hairpin RNA (shRNA) or shRNA for Prx1. Transfected cells were cultured and selected with puromycin (Sigma-Aldrich) for gene expression analysis. For 5-bromodeoxy uridine (BrdU) staining, mouse NSCs were transfected by the Nucleofection system with a control vector and an shRNA for Prxl vector that coexpresses EGFP for $48 \mathrm{~h}$, and were then cultured with $10 \mu \mathrm{M}$ BrdU for $1 \mathrm{~h}$. The BrdU-treated cells were fixed with paraformaldehyde (PFA) and acid treated, followed by immunofluorescence analysis with a BrdU-specific antibody (Accurate). Non-acid-treated cells were stained with an anti-phospho-Histone H3 (Ser10) antibody (Cell Signaling Technology), and nuclei were stained with DAPI.

Immunohistochemistry. Tissue and cells were fixed with PFA and processed for immunostaining as described previously (Lie et al., 2005). Primary antibodies included rabbit anti-Prxl (gift from M. Kern, Medical University of South Carolina), rabbit anti-GFP (MBL), chicken anti-GFP (Aves Labs), rabbit anti-Sox2 (Millipore Bioscience Research Reagents), mouse anti-Sox2 (R\&D Systems), mouse antiNeuN, rabbit anti-NG2 (Millipore Bioscience Research Reagents), goat anti-DCX and goat anti-Nestin (Santa Cruz Biotechnology), mouse anti-S100 $\beta$ (Sigma-Aldrich), mouse anti- $\beta$ III-tubulin (Sigma), rabbit anti-active Caspase-3 (BD PharMingen), and guinea pig anti-GFAP (Advanced ImmunChemical). Nuclei were stained with 4',6-diamidino-2-phenylindole (DAPI) or TO-PRO-3 iodide (Invitrogen). Secondary antibodies were obtained from the The Jackson Laboratory. Stained sections were visualized using a Zeiss LSM510 confocal microscope system.
Luciferase reporter assay. Luciferase assays were performed as described previously (Shimozaki et al., 2012). Luciferase reporters with repeats of the putative Prx1-binding consensus sequence, 5'-TAATTAA-3', were introduced into a vector with a $t k$ minimal promoter driven by a firefly luciferase construct. This construct was designated $6 \times$ PBS-tk-luciferase. Rat AHPs were transiently transfected with $6 \times$ PBS-tk-luciferase along with the expression vector for Sox2 (pEF-Sox2) or Prx1 (pEF-Prx1a) and pCMV-Rluc using LT-1 (Mirus). After $48 \mathrm{~h}$, cells were lysed in passive lysis buffer (Promega), and the luciferase activity was measured using the dual luciferase reporter assay system (Promega). All reporter assays were performed in triplicate, and the bars in the figures show the SDs.

Gene expression microarray analysis and quantitative real-time $R T$-PCR. One-color microarray analysis for global gene expression was performed using SurePrint G3 and GeneSpring GX (Agilent Technologies) by Hokkaido System Science, according to the manufacturer's protocol. Quantitative real-time RT-PCR (qRT-PCR) was performed as described previously (Shimozaki et al., 2012). Briefly, total RNAs were extracted using the RNeasy kit (Qiagen) and reverse-transcribed using ReverTra Ace- $\alpha$ - kit (TOYOBO). qRT-PCR was performed with an SYBR green Q-PCR analysis kit (Takara). All samples were run in quadruplicate for each experiment (Applied Biosystems), and values were normalized to those for glyceraldehyde-3-phosphate dehydrogenase (Gapdh). The primers used for qRT-PCR are as follows: Prxl: 5'-GAACTCTGAGGAGAAGAAGAA GAG-3', 5'-GCAGTCACGTCTCCTGAGTAG-3', Fgfr2: 5'-ATAAGGTAC GAAACCAGCACTG-3', 5'-GGTTGATGGACCCGTATTCATTC-3', Pten: 5'-AATTCCCAGTCAGAGGCGCTATGT-3', 5'-GATTGCAAGTTCC GCCACTGAACA-3', Akt2: 5' -CCTTTGTCATACGCTGCCTG-3', 5' GATAGCCCGCATCCACTCTTC-3', Cdk1c/p57: 5'-GCAGGACGAGA ATCAAGAGCA-3', 5'-GCTTGGCGAAGAAGTCGTT-3', Rasllob: 5'-GACAGCTTTGAGTACGTCAAGA-3' , 5' -TAGCCGCACTTCCAG GTCT-3', Ascl1: 5' -ACTTGAACTCTATGGCGGGTT-3', 5' -CCAGTT GGTAAAGTCCAGCAG-3', Gfap: 5' -ATCGAGATCGCCACCTACAG3', 5'-CTCACATCACCACGTCCTTG-3', S100ß: 5'-GCTGACCACCAT GCCCCTGTAG-3', 5' -CTGGCCATTCCCTCCTCTGTC-3', Nestin: 5' GAGCCATTGTGGTCTACGGAAG-3', 5'-TCCCCTAACTCATCTGC CTCA-3', Blbp: 5' -GGAAGCTGACAGACAGCCAGA-3', 5' -CGCCCA GAGCCTTCATGTAC-3', Nr5a2: 5'-GGGGCAGAAATAAGTTTGGG C-3' 5' $^{\prime}$-TTGGAGGCGGAATGAATGTTC-3', Musashi-1: 5' -TAGTTC GAGGGACAGGCTCT-3', 5'-GTTGAGGGACAGGCAGTAGC-3', Gapdh: 5'-AGGTCGGTGTGAACGGATTTG-3'， 5'-TGTAGACCATGTAGTT GAGGTCA-3'.

Retrovirus production, injections, and animals. Mouse Prxla cDNA was subcloned into a Moloney murine leukemia retrovirus vector, CAG-IRES-GFP (a gift from I. Verma, Salk Institute of Biological Studies). The transgene is driven by a CAG promoter containing the CMV enhancer/chicken $\beta$-actin promoter, a large synthetic intron, and IRESGFP. We designed this construct as CAG-Prxl. The control viral vector expressed IRES-GFP or mRFP1, which we designed as CAG-GFP or CAG-RFP, respectively. Each retrovirus was produced as described previously (Zhao et al., 2006) and titers ranged between 2.5 and $5 \times 10^{7}$ $\mathrm{cfu} / \mathrm{ml}$. All mice used in this study were 8-week-old female C57BL/6 mice (Harlan or Japan SLC). Animal procedures were performed in accordance with protocols approved by the Institutional Animal Care Use Committee of the Salk Institute for Biological Studies and the Animal Care and Use Committee of Nagasaki University. Mice were stereotactically injected with $1 \mu \mathrm{l}$ of CAG-GFP or CAG-Prx1 into the DG (coordinates from bregma were -2 anteroposterior, \pm 1.5 mediolateral and -2.3 dorsoventral from skull). For viral cocktails, CAG-RFP and CAG-GFP or CAG-Prx1 was mixed in a 1:1 volume, and then 1.5 $\mu \mathrm{l}$ of this mixture was injected. Virus-labeled GFP- or mRFP1expressing cells were analyzed at $1 \mathrm{~d}, 4 \mathrm{~d}, 7 \mathrm{~d}$, or 4 weeks postinjection for the expression of NeuN, DCX, active Caspase-3, Sox2, NG2, Nestin, or GFAP with immunohistochemistry throughout the rostrocaudal extent of the DG.

Statistical analysis. All data are reported as mean \pm SD and were analyzed by a two-tailed paired Student's $t$ test. $p$ values $<0.01$ were considered significant. 
A

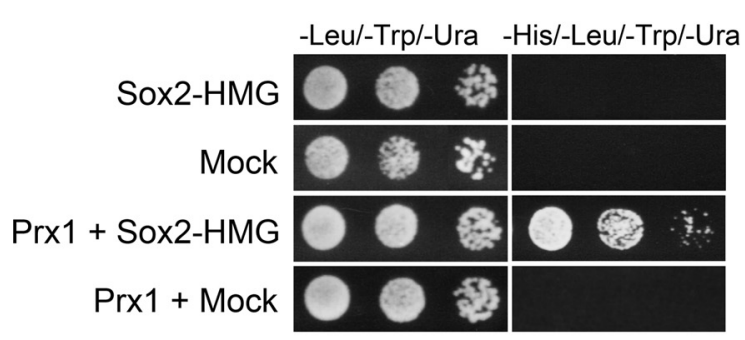

B

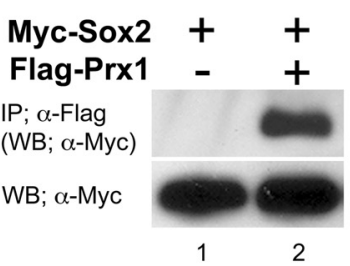

D

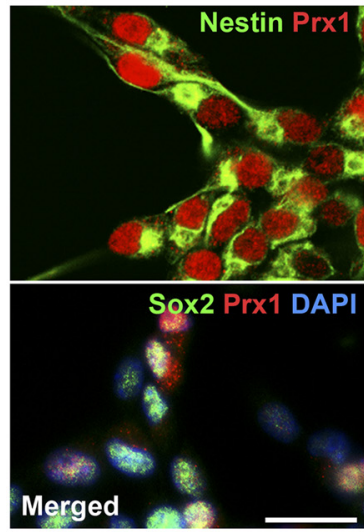

C

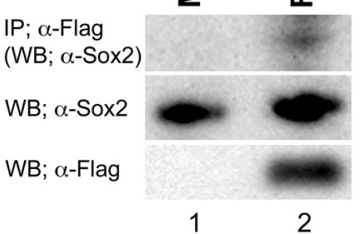

2

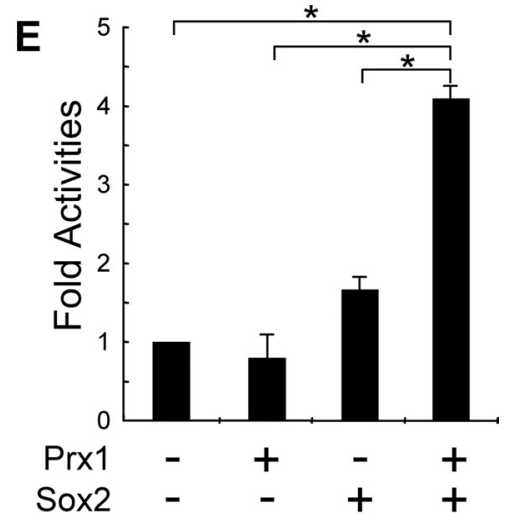

$\mathbf{F}$

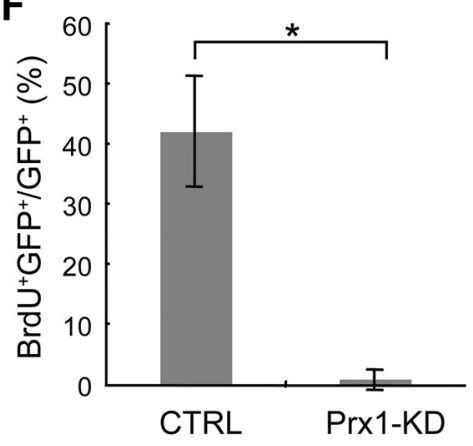

G

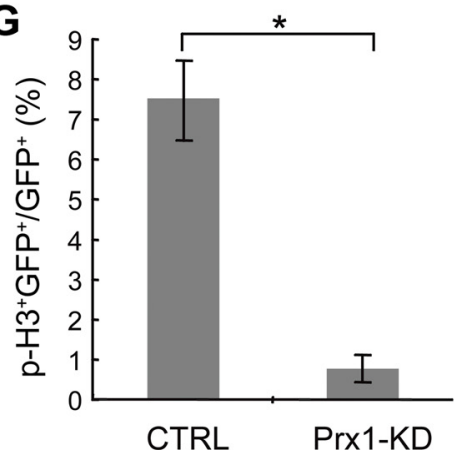

Figure 1. Prx1 is a novel binding partner for Sox2 and regulates the stemness of adult mouse NSCS.A, Yeast two-hybrid binding assay between Sox2 and Prx1. Sox2-HMG (136 -352 aa) was fused to the GAL4 DNA binding domain to be used as bait for full-length mouse Prx1a fused to the GAL4 activation domain. To evaluate binding, the transformants were cultured on selective medium plates lacking tryptophan, leucine, and uracil, and with or without histidine. B, Prx1 and Sox2 interact in mammalian cells. Flag-tagged Prx1a and Myc-tagged Sox2 proteins were transiently coexpressed in $293 \mathrm{~T}$ cells, and equal amounts of the total extracts were immunoprecipitated with anti-Flag antibody. Total Myc-Sox2 expression (bottom) and coimmunoprecipitated Myc-Sox2 (top) was detected by anti-Myc immunoblotting. C, Interaction of endogenous Sox2 protein with Prx1. Flag-tagged Prx1a protein was transiently expressed in adult mouse NSCs. Equal amounts of nuclear extracts were immunoprecipitated with anti-Flag antibody. Coimmunoprecipitated Sox2 was detected with anti-Sox2 antibody (top). The expression of Sox2 and Flag-Prx1a proteins in nuclear extracts was determined by anti-Sox2 (middle) or anti-Flag (bottom) immunoblots. D, Prx1 protein (red) is detected with Sox2 (green; bottom, left) in the nucleus of cultured adult mouse NSCs that express Nestin (green; top, left). Nuclei are visualized with DAPI. Scale bar, $20 \mu \mathrm{m}$. E, The Prx1 reporter luciferase construct (6×PBS-tk-luc) was transfected with the pEF mock vector for control (-), pEF-Prx1a (Prx1), or pEF-Sox2 (Sox2) into ratAHPs. Luciferase activity was measured and normalized with pCMV-RLuc. Assays were performed in triplicate and the error bars indicate the SD. Adult NSCs from mice were transfected with a control vector, Prx 1 shRNA. Cells were cultured for $2 \mathrm{~d}$ and then treated with BrdU for $1 \mathrm{~h}$. Cells were fixed with $4 \%$ paraformaldehyde and stained with anti-BrdU or anti-phospho-Histone H3 (p-H3) and anti-GFP antibodies, and each positive cell was counted. The percentage of GFP and BrdU (F) or p-H3 (G) to GFP-positive cells is shown. * $p<0.01$.

\section{Results}

Prx1 coactivates transcription with Sox 2 and regulates selfrenewal of adult NSCs

The transcription factor Sox 2 is an essential factor in maintaining the stemness of adult NSCs (Ferri et al., 2004). Sox2 regulates target genes through a variety of partner factors (Kondoh and Kamachi, 2010). To identify these factors in adult NSCs, we screened a cDNA library of adult NSCs prepared from mice, using a yeast-two-hybrid system. The HMG-box domain of Sox2 was used as bait because it is an essential region for forming complexes with partner factors. We identified two positive clones: one contained cDNA fragments of the paired-related ho- meobox gene Prx1 and the other contained another paired-type homeobox gene, Pax6, which is a known Sox 2 partner (Kamachi et al., 2001). The binding between the HMG-box domain of Sox2 and Prx 1 was able to drive the Gal4/UAS-HIS3 system and permit growth of yeast on histidine-deficient medium (Fig. 1A). We then wanted to confirm the association between Sox 2 and Prx1 in mammalian cells. For this purpose, we performed a coimmunoprecipitation analysis of Myc-tagged Sox 2 and Flag-tagged Prx1a in $293 \mathrm{~T}$ cells. When lysates expressing both Myc-Sox2 and FlagPrxla were immunoprecipitated with an anti-Flag antibody, a significant amount of Myc-Sox2 protein was coprecipitated (Fig. $1 B$, lane 2). We also show that overexpressed Prx 1 protein formed 

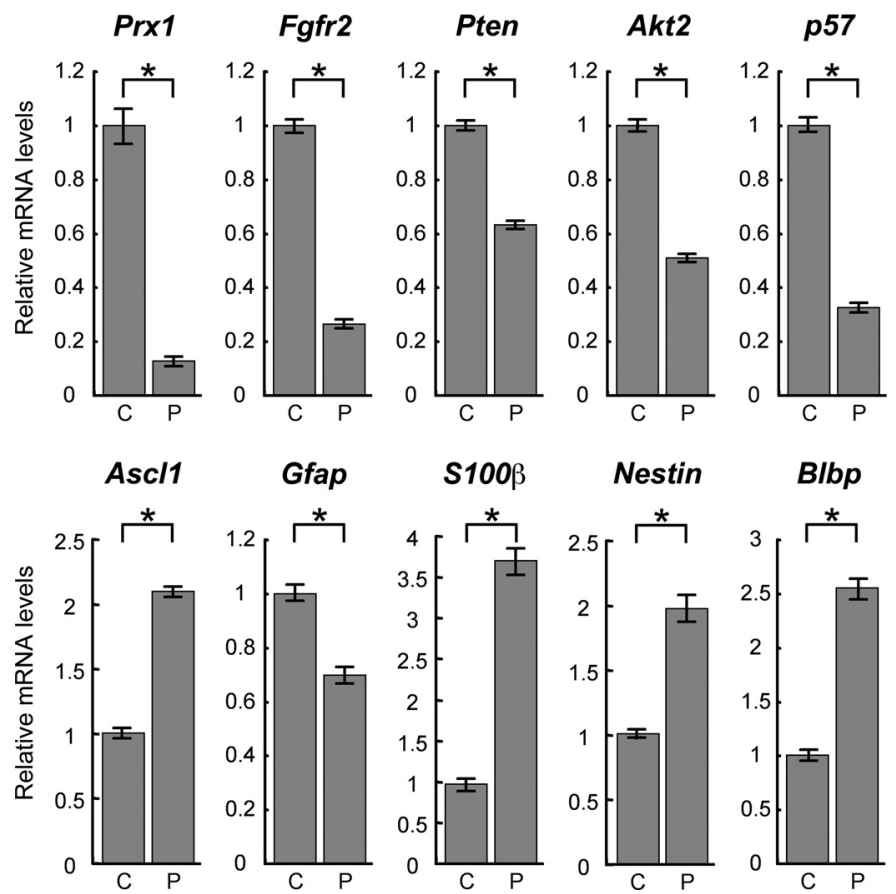

Figure 2. Prx1-dependent expression of selected key stemness genes for NSCs in control or Prx1-depleted adult mouse NSCS. Adult mouse NSCs were transfected with vectors for scrambled control shRNA (CTRL; $C$ ) or Prx1 shRNA (Prx1-KD; P) and cultured for 3 d. Transfected cells were selected with puromycin and analyzed by $q$ RT $-P C R .{ }^{*} p<0.01$.

a complex with endogenous Sox 2 protein in adult mouse NSCs (Fig. 1C, lane 2), suggesting that a molecular interaction between these proteins can occur in adult NSCs. We then performed immunostaining analysis of Prx1 protein in cultured adult NSCs from whole murine forebrain by confocal microscopy. As shown in Figure $1 D$, Prx1 was expressed in the nuclei of all Nestin ${ }^{+}$adult NSCs (top, left), and Prx1 was colocalized with Sox2 in the nuclei of cultured adult NSCs (bottom, left). To more closely examine the relationship between Sox 2 and Prx1 in regulating transcription in adult NSCs, we prepared luciferase reporter constructs that contained a minimal $t k$ promoter with multimerized Prx 1 binding sites. As shown in Figure 1E, Prxl alone did not affect the transcriptional activity of this reporter in adult hippocampus stem/ progenitor cells (AHPs). However, when an equimolar ratio of Sox2 and Prxl is expressed in AHPs, activation of this reporter was synergistically enhanced compared with Sox 2 alone. These results indicate that Sox2 functions as a coactivator with Prx1 in regulating transcriptional activity in AHPs.

To investigate how Prx1 may be related to the stemness of adult NSCs, we constructed shRNA expression vectors that contained GFP and the shRNA sequence of Prx1 (Prx1-KD) or a scrambled control (CTRL). Adult NSCs were transfected with these shRNA vectors and we measured cell proliferation using BrdU and phospho-Histone $\mathrm{H} 3$ (p-H3) labeling, which is a proliferation marker of dividing cells. As shown in Figure 1, $F$ and $G$, expression of Prx1 shRNA significantly decreased both BrdU incorporation and $\mathrm{p}-\mathrm{H} 3$ labeling compared with the control vector. To understand the effects of Prx 1 knockdown, we profiled the mRNA expression in adult NSCs with a DNA microarray. Adult NSCs were transfected with Prx1-KD or CTRL and then selected with puromycin. mRNA was extracted after $72 \mathrm{~h}$ and analyzed by a gene expression microarray system. Under Prxl knockdown conditions the majority of the 24,162 analyzed genes showed little differences from control conditions. However, the gene ontology analysis of the DNA microarray data by Prx 1 knockdown, using a
Ras/10b

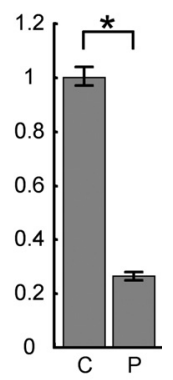

$\mathrm{Nr} 5 \mathrm{a} 2$

$p$ value cutoff of 0.01 , showed that the categories of "cellular process" and "multicellular organismal process," such as cell adhesion molecules and genes involved in vasodilation system, were upregulated. In contrast, the categories of "response to stimulus" and "immune system process," such as MHC class I protein complex and peptide antigen binding group, were downregulated (the analyzed DNA microarray list is provided on request). Therefore, to elucidate the specific role of Prx1 signaling, we identified specific genes from the analyzed DNA microarray that were related to NSC regulation. To validate the gene expression changes between control and Prxl knockdown, we performed qRT-PCR on several candidate genes (Fig. 2). Prx 1 transcript was reduced to only $17 \%$ of the control by the Prx 1 shRNA knockdown. We also found that the expression levels of genes that regulate proliferation were reduced by $\operatorname{Pr} x 1$ knockdown, including Fgfr2 and $A k t 2$, which promote proliferation of NSCs, and tumor suppressor genes such as p57, Pten, and Rasl10b. Prx1 knockdown also reduced the expression of Gfap, a marker for astroglia and NSCs, and the nuclear receptor Nr5a2, which has a reprogramming ability to produce induced pluripotent stem cells (iPSCs). Interestingly, the neuronal marker gene Ascl1/ Mash 1 and astroglial marker gene $S 100 \beta$ were both upregulated after Prx 1 knockdown, as were the NSC markers Nestin and Blbp. In contrast, we detected no difference in expression of another marker for NSCs, Musashi-1, between control and Prx1 knockdown cells by qRT-PCR analysis ( $p=0.35$; Student's $t$ test). These data suggest that the knockdown of Prx1 affected the molecular program regulating proliferation in NSCs. Moreover, the balance to maintain NSCs in an undifferentiated state versus their induction into differentiated neural lineages was also disrupted by $\operatorname{Pr} x 1$ knockdown. Together, these data indicate that Prx1 plays an important role in regulating genes that control the selfrenewal and stemness of adult NSCs.

\section{Sox $2^{+} / \mathrm{GFAP}^{+} / \mathrm{Nestin}^{+}$astrocytes in the adult forebrain express Prx1}

There are two different stem cell niches in the adult brain: the SVZ of the lateral ventricle and the SGZ of the hippocampus (Zhao et al., 2008). During the characterization of Prx1 in the initial phase of this study, we used cultured adult NSCs derived from whole brains of adult mice that contained both of the germinal zones. Therefore, we analyzed the protein expression of Prx1 in each stem cell niche (SVZ and SGZ) of adult mouse brains by immunostaining techniques. We first confirmed the expression of Prx1 in the SVZ of the lateral ventricle, where it was expressed in Sox $2^{+} / \mathrm{GFAP}^{+}$cells in the SVZ as indicated by an arrow in Figure $3 A$. We also analyzed the coimmunoreactivity of S100 $\beta$, a marker for ependymal cells, and DCX, a marker for neural progenitors with Prx1 in the SVZ. As shown in Figure 3B, the dense and linear $S 100 \beta$-positive ependymal cell layer (indicated by an arrowhead) and Prx1-positive cells (indicated by an arrow) are detected in different areas of the SVZ. Though DCX-positive neural progenitors form neuroblast clusters in 
A

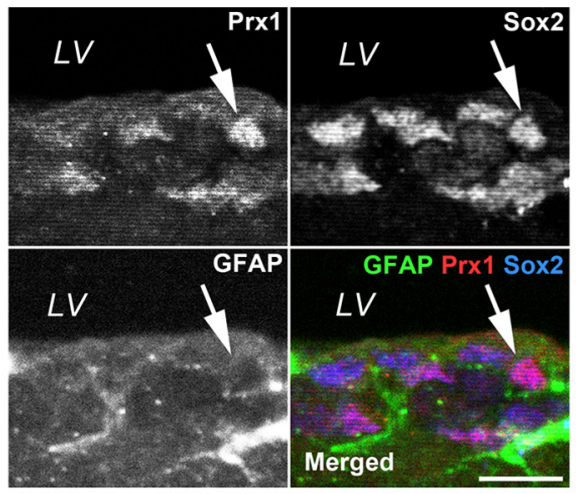

C

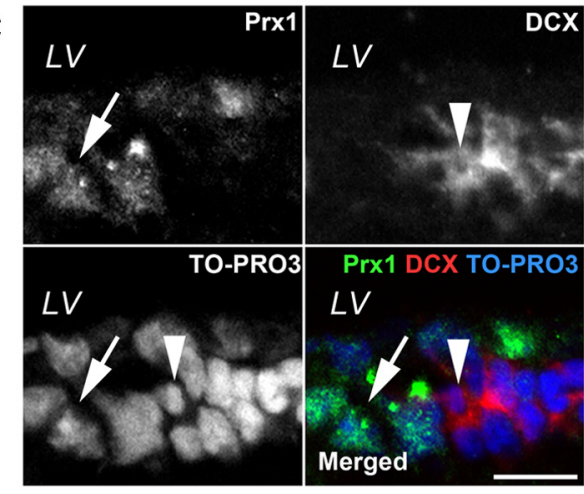

E

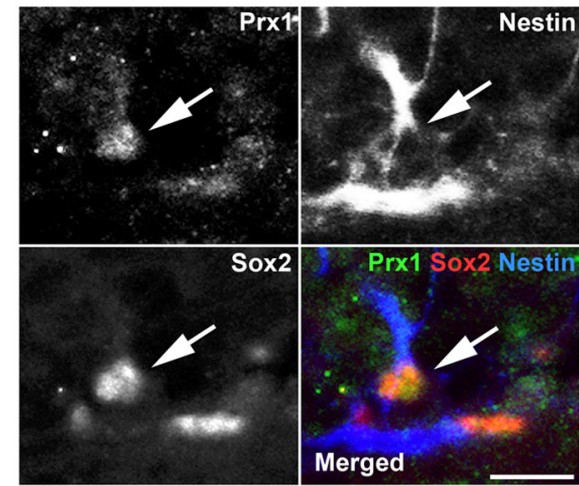

G

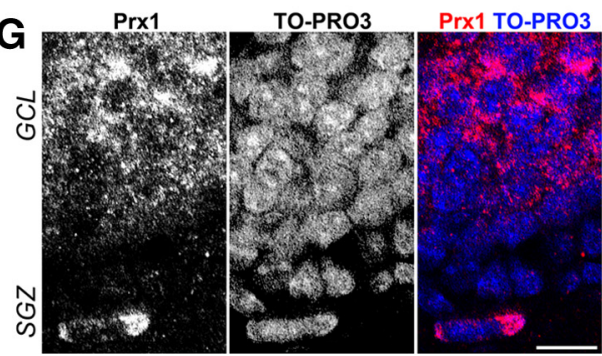

B

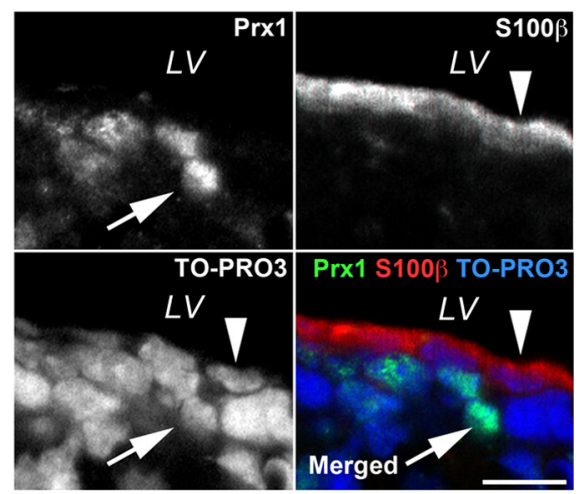

D

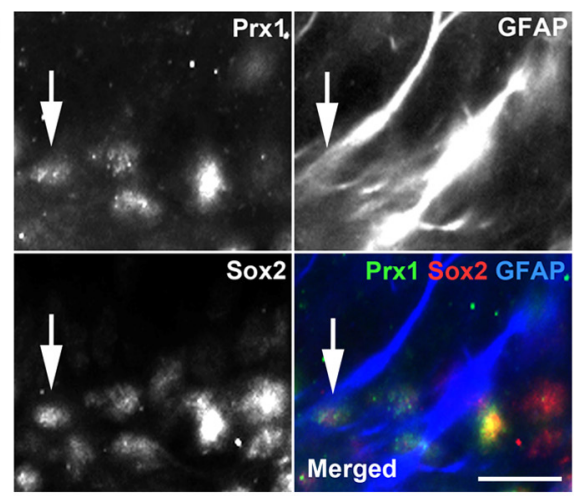

$\mathbf{F}$
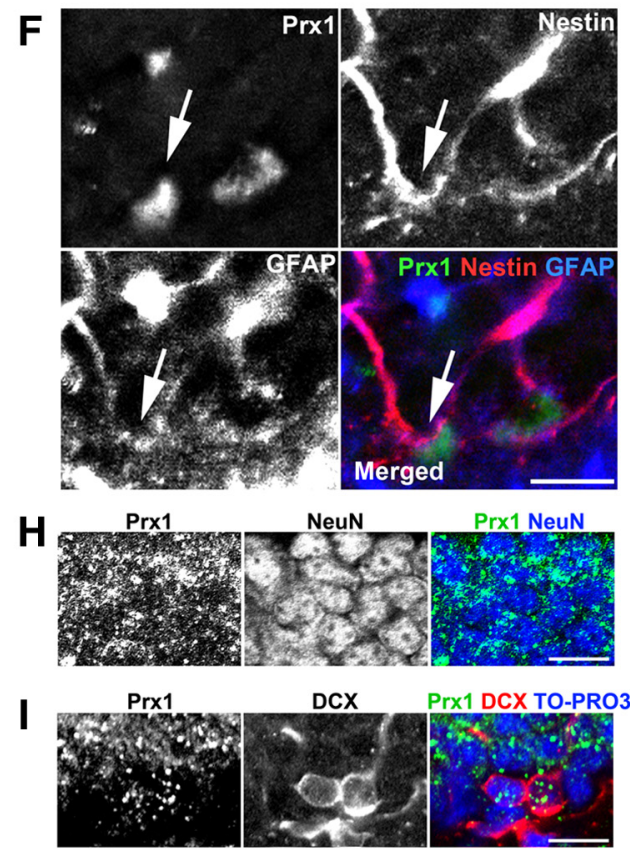

Figure 3. Expression of Prx1 in the SVZ and SGZ of the adult mouse forebrain. $A$, Prx1 (red) is expressed in Sox2 (blue) and GFAP (green) double-positive cells in the SVZ. The majority of Prx1-expressing (green) cells do not express $S 100 \beta$ (B; red) or DCX (C; red) in the SVZ. LV, lateral ventricle. D, The GFAP (blue) and Sox2 (red) double-positive cells in the SGZ express Prx1 (green). $\boldsymbol{E}$, The Nestin (blue) and Sox2 (red) double-positive cells in the SGZ also express Prx1 (green). $\boldsymbol{F}$, Prx1 (green) is expressed in Nestin (red) and GFAP (blue) double-positive cells in the SGZ. G, Prx1 (red) is largely confined within the nucleus of cells in the SGZ, but marked signals are also observed in the cytoplasm of cells in the GCL. $\boldsymbol{H}$, Prx 1 (green) signals are largely confined to the cytoplasm of NeuN-positive (blue) cells. I, Some Prx1 have a speckled appearance (green) in the nucleus of DCX-positive (red) cells in the SGZ. Nuclei are visualized with T0-PR03. Scale bars, 20 $\mu \mathrm{m}$.

the SVZ, as shown in Figure 3C (indicated by an arrowhead), they are not colocalized with Prx1-positive cells (indicated by an arrow).

Next, we focused on the protein expression of Prx1 in another neural stem cell niche, the SGZ of the hippocampus. Prx1 protein was expressed in Sox ${ }^{+} / \mathrm{GFAP}^{+}$cells in the SGZ of the hippocampus as indicated by an arrow in Figure $3 D$. Moreover, we also detected $\operatorname{Prx} 1^{+} /$Sox $2^{+} /$Nestin $^{+}$cells (Fig. $3 E$, arrows), and
$\operatorname{Prxl}^{+} / \mathrm{Nestin}^{+} / \mathrm{GFAP}^{+}$cells (Fig. $3 F$, arrows) in the SGZ. Thus, these data demonstrate that Prx1 is specifically expressed in Sox $2^{+} / \mathrm{GFAP}^{+} / \mathrm{Nestin}^{+}$astrocyte-like cells, that are most likely NSCs, in the adult germinal zone of mouse forebrain. Interestingly, Prxl exhibited a speckled localization within the cytoplasm and in some nuclei in the granular cell layer (GCL) of the hippocampus (Fig. 3G) that were also positive for the mature neuronal marker NeuN (Fig. 3H). As shown in Figure 3I, some Prx1 


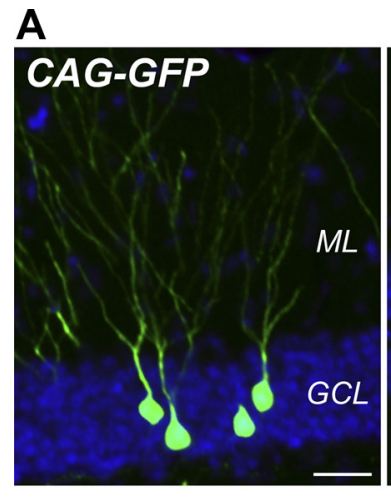

C

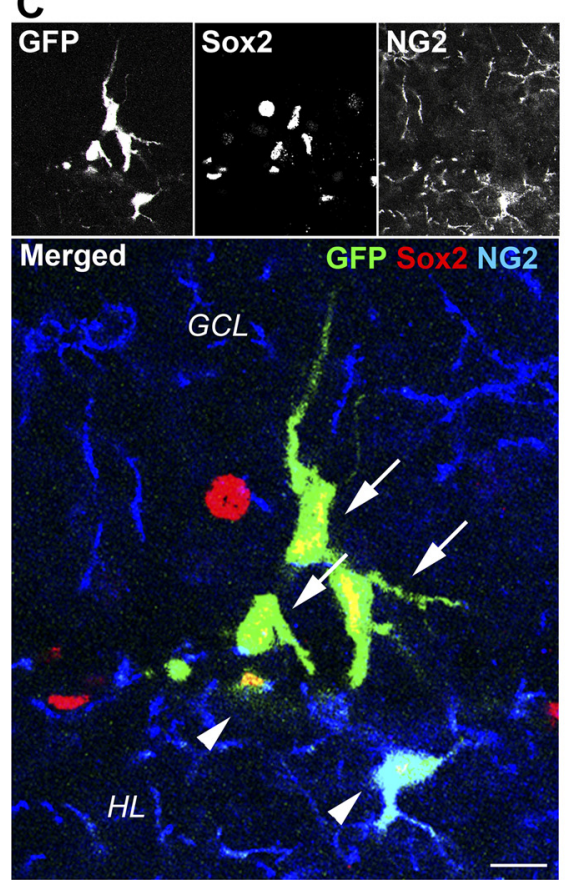

B
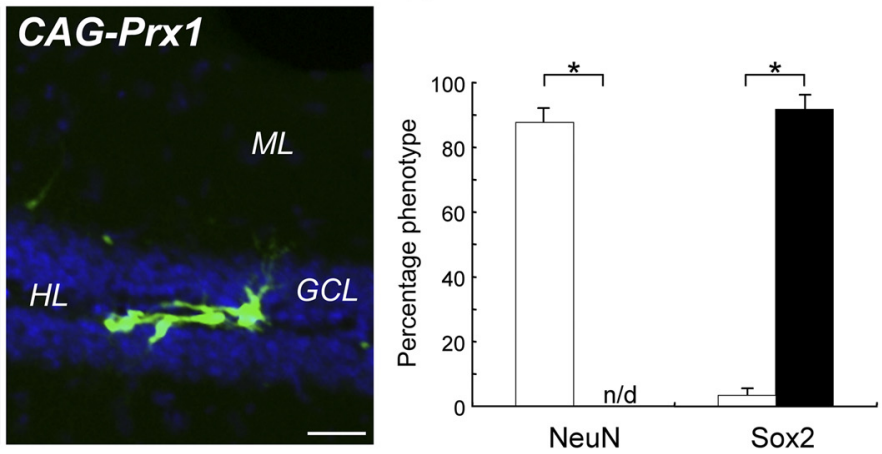

D

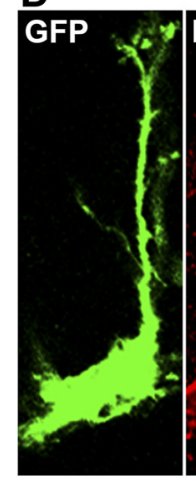

Nestin

CFAP

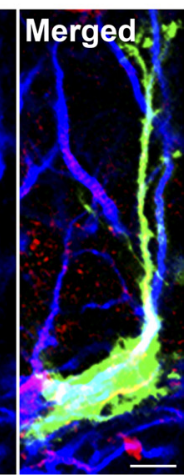

E

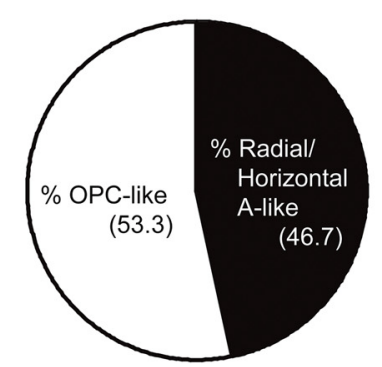

Figure 4. Prx1 redirects the glial stem/progenitor cell fate of hippocampal stem/progenitor cells in the adult mouse brain. $\boldsymbol{A}$, Ectopic Prx1 expression changes the morphology of newborn cells in the adult mouse DG. The majority of Control GFP-expressing retrovirus-labeled (green) newborn cells become typical granule neurons 4 weeks after the injection of the retrovirus (left). Retroviral expression of Prx1-induced (right) morphological changes in these cells. B, Quantification of newborn cells 4 weeks after injection of CAG-GFP (white bars) or CAG-Prx1 (black bars) revealed that cells overexpressing Prx1 completely lost the expression of NeuN and rather almost exclusively expressed Sox2. ${ }^{*} p<0.01$. C, Radial/horizontal (arrows) and 0PC-like (arrowheads) shaped progeny of Prx1-overexpressing cells (green) stained with anti-Sox2 (red) and anti-NG2 (blue) antibodies. D, Radial and horizontal morphologies of Prx1-0verexpressing cells colabeled with both Nestin (red) and GFAP (blue). $E$, The percentages of cells recognized as radial/horizontal astrocyte (A)-like or OPC-like morphology in Sox2-positive cells 4 weeks after CAG-Prx1 injection. GCL, granular cell layer; ML, molecular layer; HL, hilus. Scale bars: $\boldsymbol{A}, 50 \mu \mathrm{m} ; \boldsymbol{C}, 10 \mu \mathrm{m} ; \boldsymbol{D}, 20 \mu \mathrm{m}$.

speckled labeling was also detected in the nucleus of $\mathrm{DCX}^{+}$cells in the SGZ of the hippocampus.

Prx1 redirects the fate of newborn cells from hippocampal stem/progenitor cells in the SGZ of the adult brain

As shown in Figure 3, Prx1 was expressed in the nucleus of NSCderived astrocytes in vivo. Furthermore, a speckled localization of Prx1 was detected in the nucleus of neuronal progenitors of the SGZ and in the cytoplasm of mature neurons of the GCL in the hippocampus. To elucidate the role of Prx1 in the nucleus of NSCs in vivo, we constitutively expressed exogenous Prx1 in the nucleus of dividing cells in the SGZ of the adult mouse hippocampus. Four weeks after intrahippocampal injection of a GFP-expressing retrovirus (CAG-GFP; Fig. 4A, left), the majority of newborn cells had the typical highly polarized morphology of granule neurons. However, cells expressing CAG-Prxl exhibited a remarkably altered morphology (Fig. $4 A$, right). Unlike the newborn granule neurons, which remained in the inner layers of the GCL, a number of Prx1-overexpressing cells either remained within the SGZ or migrated into the hilus. This demonstrates that Prxl overexpression modified the behavior of cells in the SGZ compared with control cells.

While we observed that most newborn cells labeled with CAGGFP expressed neuronal marker neuronal nuclei (NeuN; $87.7 \pm$ $3.2 \%$ ), we were unable to detect NeuN expression in cells expressing CAG-Prx1. Instead, the cells expressing CAG-Prx1 almost exclusively colabeled with Sox2 $(91.7 \pm 3.5 \%)$, a marker for NSCs. In contrast, few $(3.3 \pm 1.2 \%)$ CAG-GFP-expressing cells were colabeled with Sox2 (Fig. 4B). We were able to identify morphologically distinct types of Prx1-overexpressing cells colabeled with Sox 2 in the adult hippocampus by confocal microscopy and lineage marker profiling: oligodendrocyte precursor cell (OPC)-like and radial/horizontal astrocyte-like. Only OPC-like cells overexpressing Prx1 colabeled with NG2 (Fig. 4C, arrow- 
heads), those with radial and horizontal glial morphology (Fig. 4C, arrows), did not. To more carefully describe these cells, we performed immunohistochemistry with specific markers for neural stem/progenitor cells. As shown in Figure $4 D$, the radial/horizontal shaped cells overexpressing Prx1 colabeled with radial glial NSC markers such as Nestin and GFAP, particularly in their radial processes and somas. In contrast, the Prx1overexpressing Sox $2^{+} / \mathrm{NG}^{+}$OPC-like cells did not colabel with Nestin, GFAP, or DCX, a marker for immature neurons (data not shown). As shown in Figure 4E, overexpression of Prx1 generated similar numbers of OPC-like and radial/horizontal astrocyte-like cells (53.3 and 46.7\%, respectively).

The generation of undifferentiated cells by overexpressing Prxl occurred at the expense of generating newborn neurons, as shown in Figure 4. Interestingly, Prx1-overexpressing and control AHPs were indistinguishable $24 \mathrm{~h}$ after virus injection, and the number of cells expressing Sox2 did not significantly differ between them at this time point. To determine whether Prxl expression also affected cell death, we injected a control GFP virus or a Prx1-expressing virus into the SGZ of the hippocampus. After $7 \mathrm{~d}$, we immunostained for DCX and activated Caspase-3, a marker for apoptotic cells. Interestingly, Prx1 cells did not colocalize with DCX (Fig. $5 A$, bottom), in contrast to control GFP-positive cells (Fig. 5A, top). Moreover, there was no immunoreactivity for active Caspase- 3 in either cell (Fig. 5A). To further examine the cell death of infected cells, we first checked the difference in viral tropism between CAG-GFP and CAG-Prx1 viruses. We coinjected CAG-GFP or CAG-Prx1 retrovirus with RFP-expressing control virus and found that Prxl-targeted cells were also transduced with the RFP virus. There were no significant differences in the number of CAG-GFP or CAG-Prx1 viruses alone, or colabeled with the RFP virus (Fig. 5B). These data indicate that the viral transduction of CAG-Prxl occurred in the same cell population that was transduced with the RFP-expressing control virus. We next measured the densities of wild-type (RFP-positive only) and Prx1-expressing GFP-positive newborn cells in mice 4-7 d after virus injection in the SGZ to further confirm the viability of virus-infected cells in vivo. Neither of the viruses showed any loss of the normalized densities, and no statistical difference was found between RFP-positive only and Prx1/GFP-positive newborn cells at $7 \mathrm{~d}$ ( $p=0.16$, Student's $t$ test; Fig. $5 C)$. Together, these data suggest that the continuous expression of Prx1 maintained the status of neural stem/glial precursor cells without influencing cell viability in the SGZ of the hippocampus.

To elucidate the cellular and environmental relationship of this phenomenon, the viral expression vectors were infected into cultured neural stem/progenitor cells derived from rat hippocampus. Interestingly, in contrast to the results in vivo, we
B
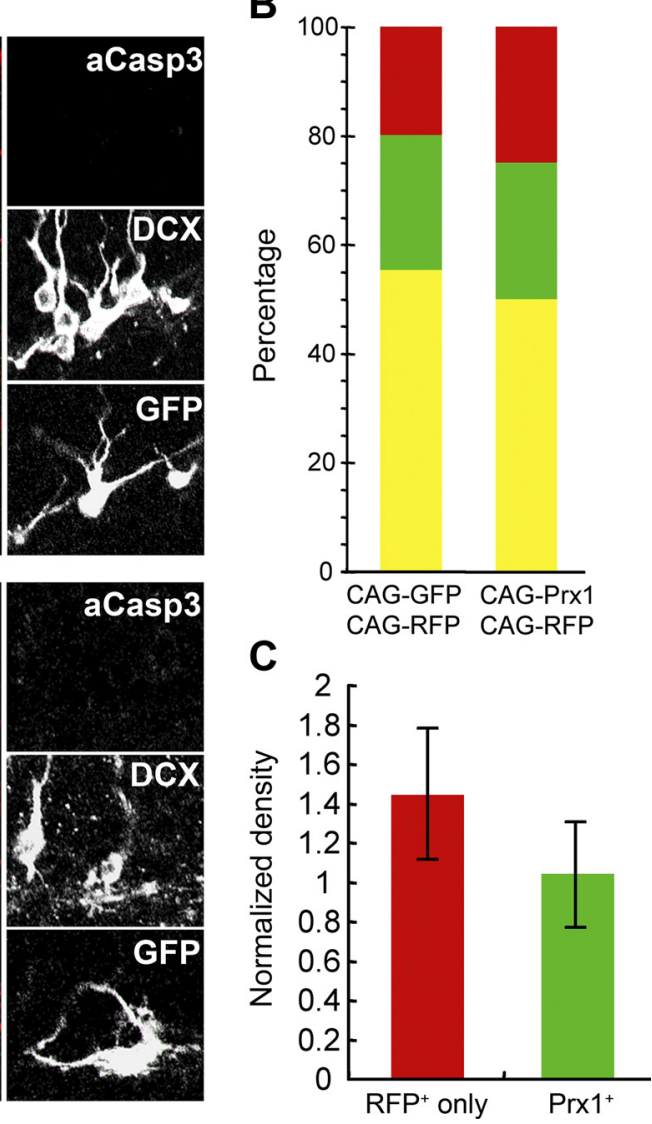

Figure 5. Continuous expression of Prx1 does not induce neuronal cell-fate differentiation or affect cell viability in the adult

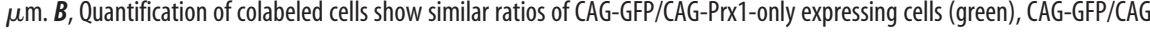
after the injection of the retrovirus in the SGZ of the hippocampus. For the calculation of the density of newborn cells in the sections, the number of newborn cells at $7 \mathrm{~d}$ was divided by the number of cells at $4 \mathrm{~d}$ with any fluorescently labeled cells.

found no significant differences in differentiated $\beta$ III-tubulinpositive neurons transduced with control or Prx1 vectors (25.2 \pm 11.0 and $27.8 \pm 10.7 \%$, respectively, mean $\pm \mathrm{SD} ; p=0.78$, Student's $t$ test; Fig. 6). These results indicate that the maintenance of undifferentiated glial-cell fates by sustained expression of Prx1 in vivo requires specific niches such as the SGZ of the hippocampus.

\section{Discussion}

The ability of Sox gene family members to change their regulatory partners is crucial for cell fate specification (Kondoh and Kamachi, 2010). Therefore, identifying these molecules and the conditions in which they bind Sox family members in vivo is important to elucidate these developmental processes. In this study, we have identified Prx1 as a novel partner for Sox2. We have also demonstrated that Prx1 controls the stemness of NSCs and is critical for neuronal/glial-fate switching in neural/stem progenitor cells in the hippocampus.

After Prx 1 knockdown, we identified a number of important gene expression changes in adult NSCs (Fig. 2). The expression of Fgfr2, a receptor for FGF-2 that controls the self-renewal of NSCs (Ray et al., 1993), was reduced by the knockdown of Prx1. Further, Prx 1 knockdown also decreased the expression of other genes essential for the self-renewal of NSCs, such as Pten and 


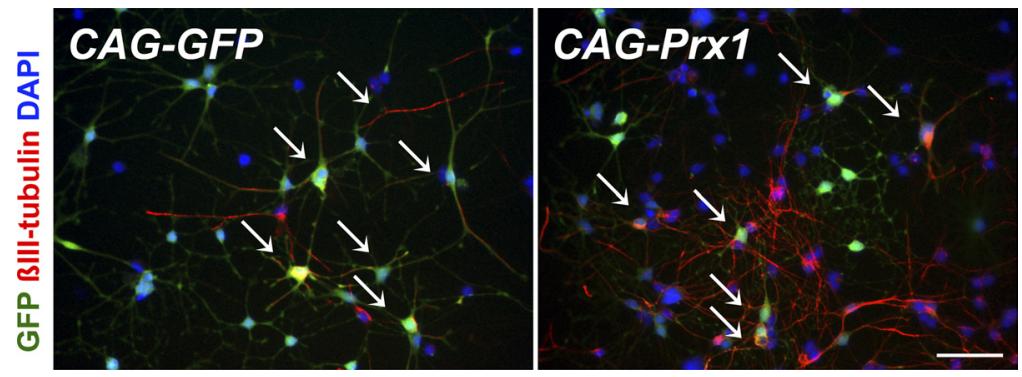

Figure 6. Prx1 overexpression does not affect the neuronal fate of cultured NSCs. AHPs isolated from adult hippocampus can generate neuronal ( $\beta$ III-tubulin, red) cells. Note that cells transduced with both CAG-GFP control virus and CAG-Prx1 expression virus at $7 \mathrm{~d}$ expressed neuronal marker $\beta$ III-tubulin (arrows). Scale bar, $50 \mu \mathrm{m}$.

$A k t 2$, which modulate cell proliferation and survival (Downward, 2004; Zhang et al., 2006). The tumor suppressor $p 57$, which was recently reported to be required for the maintenance of adult hematopoietic stem cells (Matsumoto et al., 2011), was significantly decreased in a Prxl-dependent manner. Prxl knockdown also significantly reduced $\mathrm{Nr} 5 a 2$ expression, a nuclear receptor with a similar function as Oct3/4 in iPSC-reprogramming and regulation of cell growth (Heng et al., 2010). These findings strongly suggest that Prx1 plays a pivotal role in the self-renewal of NSCs by regulating the transcription of these genes. Surprisingly, we found that Prx1-knockdown upregulated the expression of genes important for neuronal (Ascl1) and glial $(S 100 \beta)$ differentiation. Moreover, in terms of NSC regulation, Nestin and Blbp mRNA were upregulated but the levels of Musashi-1 mRNA did not change following Prx1knockdown. These data suggest that $\operatorname{Pr} x 1$ knockdown disrupted not only specific mechanisms for the maintenance of stemness but also for the differentiation of NSCs. Thus, we propose that Prx1 is involved not only in self-renewal regulation of NSCs but also in the balance between stemness and differentiation of these cells.

We demonstrated that the knockdown of Prxl dramatically reduced the self-renewal of NSCs derived from adult brains (Fig. $1 F, G)$. Prxl alone has weak transcriptional activation, but this is markedly enhanced by Sox 2 as a cofactor (Fig. $1 E$ ). These results suggest that Prx1 plays a role in the self-renewal of NSCs in conjunction with Sox2. It has been previously reported that Prx1 is involved in proliferation of vascular smooth muscle and limb cells (Ihida-Stansbury et al., 2005; Peterson et al., 2005). However, the Prx1 isoforms expressed in these cells (Prx1a and Prx1b) have different C-terminal sequences and different functions based on in vitro analyses (Peterson et al., 2005). Since both Prxla and Prx1b are expressed in cultured NSCs, we analyzed the effects of forced expression of each isoform in the DG of the adult brain, but no differences were detected (data not shown). Future analysis of the expression and function of Prxla and Prx1b should help clarify the role of the C-terminal-specific sequences of these isoforms.

Prx1 protein is expressed in the nucleus of Nestin ${ }^{+} / \mathrm{GFAP}^{+}$ astrocytes, which are putative NSCs in the adult brain, and overlaps with the expression of Sox2 (Fig. 3). Interestingly, the intensity of Prx1 immunostaining was stronger and more frequent in the SVZ compared with the SGZ. This difference in intensity and subcellular localization of Prx1 between SVZ and SGZ may reflect the different properties of the neurons that are generated by these regions. Prxl signals are largely confined to the nucleus in SGZ of Sox $2^{+} / \mathrm{Nestin}^{+} / \mathrm{GFAP}^{+}$cells. Signals were also observed in the cytoplasm of mature granule neurons in the GCL of the hippocampus, with some Prxl displaying a speckled localization in the nucleus of neuronal progenitors (Fig. 3G-I).
Prx1 activity could be regulated during neuronal development from NSCs by controlling its intracellular localization, for example, by sequestering Prx1 in differentiated cells in the hippocampus. The class III POU transcription factors, such as Brn1/2/4 and Oct6, show such regulation by subcellular localization (He et al., 1989; Alvarez-Bolado et al., 1995; Andersen and Rosenfeld, 2001; Tanaka et al., 2004).

The forced expression of nuclear Prx1 maintained NSCs in undifferentiated glial lineages and prevented them from differentiating into neurons in the hippocampus of adult brains (Fig. 4). Since the neuronal differentiation was not changed by forced expression of Prx1 in cultured NSCs (Fig. 6), the in vivo findings suggest a strong role for regulating niche factors. This observation is similar to a previous report that showed that forced expression of Ascl1 in the hippocampus of adult brains inhibits neuronal differentiation in vivo. In cultured NSCs, however, overexpression of Ascl1 not only did not inhibit neuronal differentiation, but actually enhanced it (Jessberger et al., 2008). Therefore, the niche environment plays a prominent role in neuronal differentiation in vivo. We speculate that Prx1 functions to maintain the stemness of NSCs by interacting with these niche signals.

We have focused on the transcription factor Sox 2 to clarify the molecular mechanisms controlling self-renewal and multipotency of adult NSCs, which are the main source of neurogenesis in the adult brain. NSCs are capable of both self-renewal and multipotency, and Sox 2 plays crucial roles in both of these processes (Avilion et al., 2003; Catena et al., 2004; Ferri et al., 2004; Suh et al., 2007; Pevny and Nicolis, 2010). Deletion of Sox2 in adult NSCs leads to developmental defects in the SGZ of the adult hippocampus and causes loss of Sonic hedgehog (Shh) expression (Favaro et al., 2009). Shh-signaling has important roles for the maintenance and self-renewal of adult NSCs in the SGZ (Machold et al., 2003). The transcription factor Gli2, a mediator of Shh-signaling, is an activator of Sox 2 expression in developing telencephalic neuroepithelial cells (Takanaga et al., 2009). Prx1 also has been suggested to be an upstream regulator for Shh transcription (ten Berge et al., 2001). Thus, it is possible that the combination of Prx 1 and Sox 2 could synergistically control Shh expression in a positive feedback loop in adult NSCs.

In addition to our identification of Prx1, our screen for Sox2 binding partners in adult NSCs also identified another pairedtype homeobox transcription factor, Pax6. Pax6, an established binding partner for Sox2, plays an important role in neuronal differentiation of radial glia, a type of NSC (Heins et al., 2002), by controlling a downstream factor called Fabp7 (Arai et al., 2005). It has also been reported that Pax6 functions to produce and maintain neural stem/progenitor cells in the postnatal hippocampus (Maekawa et al., 2005). Interestingly, while Sox2 upregulates Shh expression, Shh downregulates the expression of Pax6 (Briscoe et al., 2000). Our findings suggest that there may be differential levels of Sox2 regulatory partners, such as Pax6 and Prx1, dependent on Shh signaling. The temporal and spatial expression of these partners may then differentially regulate the neuronal differentiation and stemness of NSCs in the adult brain. Since deregulation of Shh signaling has been reported in mental retardation (Badano et al., 2006; Han et al., 2008) and in malignant brain tumors (Pasca di Magliano and Hebrok, 2003; Stecca 
and Ruiz i Altaba, 2005), the differential expression of regulatory partners for Sox 2 may play a role in these diseases and be a novel molecular therapeutic target.

\section{References}

Alvarez-Bolado G, Rosenfeld MG, Swanson LW (1995) Model of forebrain regionalization based on spatiotemporal patterns of POU-III homeobox gene expression, birthdates, and morphological features. J Comp Neurol 355:237-295. CrossRef Medline

Alvarez-Buylla A, Lim DA (2004) For the long run: maintaining germinal niches in the adult brain. Neuron 41:683-686. CrossRef Medline

Andersen B, Rosenfeld MG (2001) POU domain factors in the neuroendocrine system: lessons from developmental biology provide insights into human disease. Endocr Rev 22:2-35. CrossRef Medline

Arai Y, Funatsu N, Numayama-Tsuruta K, Nomura T, Nakamura S, Osumi N (2005) Role of Fabp7, a downstream gene of Pax6, in the maintenance of neuroepithelial cells during early embryonic development of the rat cortex. J Neurosci 25:9752-9761. CrossRef Medline

Avilion AA, Nicolis SK, Pevny LH, Perez L, Vivian N, Lovell-Badge R (2003) Multipotent cell lineages in early mouse development depend on SOX2 function. Genes Dev 17:126-140. CrossRef Medline

Badano JL, Mitsuma N, Beales PL, Katsanis N (2006) The ciliopathies: an emerging class of human genetic disorders. Annu Rev Genomics Hum Genet 7:125-148. CrossRef Medline

Briscoe J, Pierani A, Jessell TM, Ericson J (2000) A homeodomain protein code specifies progenitor cell identity and neuronal fate in the ventral neural tube. Cell 101:435-445. CrossRef Medline

Catena R, Tiveron C, Ronchi A, Porta S, Ferri A, Tatangelo L, Cavallaro M, Favaro R, Ottolenghi S, Reinbold R, Schöler H, Nicolis SK (2004) Conserved POU binding DNA sites in the Sox2 upstream enhancer regulate gene expression in embryonic and neural stem cells. J Biol Chem 279: 41846-41857. CrossRef Medline

Cserjesi P, Lilly B, Bryson L, Wang Y, Sassoon DA, Olson EN (1992) MHox: a mesodermally restricted homeodomain protein that binds an essential site in the muscle creatine kinase enhancer. Development 115:1087-1101. Medline

Doetsch F, García-Verdugo JM, Alvarez-Buylla A (1997) Cellular composition and three-dimensional organization of the subventricular germinal zone in the adult mammalian brain. J Neurosci 17:5046-5061. Medline

Doetsch F, Caill é I, Lim DA, García-Verdugo JM, Alvarez-Buylla A (1999) Subventricular zone astrocytes are neural stem cells in the adult mammalian brain. Cell 97:703-716. CrossRef Medline

Downward J (2004) PI 3-kinase, Akt and cell survival. Semin Cell Dev Biol 15:177-182. CrossRef Medline

Favaro R, Valotta M, Ferri AL, Latorre E, Mariani J, Giachino C, Lancini C, Tosetti V, Ottolenghi S, Taylor V, Nicolis SK (2009) Hippocampal development and neural stem cell maintenance require Sox2-dependent regulation of Shh. Nat Neurosci 12:1248-1256. CrossRef Medline

Ferri AL, Cavallaro M, Braida D, Di Cristofano A, Canta A, Vezzani A, Ottolenghi S, Pandolfi PP, Sala M, DeBiasi S, Nicolis SK (2004) Sox2 deficiency causes neurodegeneration and impaired neurogenesis in the adult mouse brain. Development 131:3805-3819. CrossRef Medline

Gage FH (2000) Mammalian neural stem cells. Science 287:1433-1438. CrossRef Medline

Galliot B, de Vargas C, Miller D (1999) Evolution of homeobox genes: Q50 Paired-like genes founded the Paired class. Dev Genes Evol 209:186-197. CrossRef Medline

Gehring WJ, Affolter M, Bürglin T (1994) Homeodomain proteins. Annu Rev Biochem 63:487-526. CrossRef Medline

Han YG, Spassky N, Romaguera-Ros M, Garcia-Verdugo JM, Aguilar A, Schneider-Maunoury S, Alvarez-Buylla A (2008) Hedgehog signaling and primary cilia are required for the formation of adult neural stem cells. Nat Neurosci 11:277-284. CrossRef Medline

He X, Treacy MN, Simmons DM, Ingraham HA, Swanson LW, Rosenfeld MG (1989) Expression of a large family of POU-domain regulatory genes in mammalian brain development. Nature 340:35-41. CrossRef Medline

Heins N, Malatesta P, Cecconi F, Nakafuku M, Tucker KL, Hack MA, Chapouton P, Barde YA, Götz M (2002) Glial cells generate neurons: the role of the transcription factor Pax6. Nat Neurosci 5:308-315. CrossRef Medline

Heng JC, Feng B, Han J, Jiang J, Kraus P, Ng JH, Orlov YL, Huss M, Yang L, Lufkin T, Lim B, Ng HH (2010) The nuclear receptor Nr5a2 can replace
Oct4 in the reprogramming of murine somatic cells to pluripotent cells. Cell Stem Cell 6:167-174. CrossRef Medline

Ihida-Stansbury K, McKean DM, Gebb SA, Martin JF, Stevens T, Nemenoff R, Vaughn J, Lane K, Loyd J, Wheeler L, Morrell NW, Ivy D, Jones PL (2005) Regulation and functions of the paired-related homeobox gene PRX1 in pulmonary vascular development and disease. Chest 128:591S. CrossRef Medline

Inoue $\mathrm{M}$, Kamachi $\mathrm{Y}$, Matsunami $\mathrm{H}$, Imada $\mathrm{K}$, Uchikawa $\mathrm{M}$, Kondoh $\mathrm{H}$ (2007) PAX6 and SOX2-dependent regulation of the Sox2 enhancer N-3 involved in embryonic visual system development. Genes Cells 12:10491061. CrossRef Medline

Jessberger S, Toni N, Clemenson GD Jr, Ray J, Gage FH (2008) Directed differentiation of hippocampal stem/progenitor cells in the adult brain. Nat Neurosci 11:888-893. CrossRef Medline

Kamachi Y, Uchikawa M, Tanouchi A, Sekido R, Kondoh H (2001) Pax6 and SOX2 form a co-DNA-binding partner complex that regulates initiation of lens development. Genes Dev 15:1272-1286. CrossRef Medline

Kempermann G, Jessberger S, Steiner B, Kronenberg G (2004) Milestones of neuronal development in the adult hippocampus. Trends Neurosci 27:447-452. CrossRef Medline

Kern MJ, Witte DP, Valerius MT, Aronow BJ, Potter SS (1992) A novel murine homeobox gene isolated by a tissue specific PCR cloning strategy. Nucleic Acids Res 20:5189-5195. CrossRef Medline

Kern MJ, Argao EA, Birkenmeier EH, Rowe LB, Potter SS (1994) Genomic organization and chromosome localization of the murine homeobox gene Pmx. Genomics 19:334-340. CrossRef Medline

Kondoh H, Kamachi Y (2010) SOX-partner code for cell specification: regulatory target selection and underlying molecular mechanisms. Int J Biochem Cell Biol 42:391-399. Medline

Kuratani S, Martin JF, Wawersik S, Lilly B, Eichele G, Olson EN (1994) The expression pattern of the chick homeobox gene gMHox suggests a role in patterning of the limbs and face and in compartmentalization of somites. Dev Biol 161:357-369. CrossRef Medline

Leussink B, Brouwer A, el Khattabi M, Poelmann RE, Gittenberger-de Groot AC, Meijlink F (1995) Expression patterns of the paired-related homeobox genes MHox/Prx1 and S8/Prx2 suggest roles in development of the heart and the forebrain. Mech Dev 52:51-64. CrossRef Medline

Lie DC, Colamarino SA, Song HJ, Désir é L, Mira H, Consiglio A, Lein ES, Jessberger S, Lansford H, Dearie AR, Gage FH (2005) Wnt signalling regulates adult hippocampal neurogenesis. Nature 437:1370-1375. CrossRef Medline

Lugert S, Basak O, Knuckles P, Haussler U, Fabel K, Götz M, Haas CA, Kempermann G, Taylor V, Giachino C (2010) Quiescent and active hippocampal neural stem cells with distinct morphologies respond selectively to physiological and pathological stimuli and aging. Cell Stem Cell 6:445-456. CrossRef Medline

Machold R, Hayashi S, Rutlin M, Muzumdar MD, Nery S, Corbin JG, GritliLinde A, Dellovade T, Porter JA, Rubin LL, Dudek H, McMahon AP, Fishell G (2003) Sonic hedgehog is required for progenitor cell maintenance in telencephalic stem cell niches. Neuron 39:937-950. CrossRef Medline

Maekawa M, Takashima N, Arai Y, Nomura T, Inokuchi K, Yuasa S, Osumi N (2005) Pax6 is required for production and maintenance of progenitor cells in postnatal hippocampal neurogenesis. Genes Cells 10:1001-1014. CrossRef Medline

Martin JF, Bradley A, Olson EN (1995) The paired-like homeo box gene MHox is required for early events of skeletogenesis in multiple lineages. Genes Dev 9:1237-1249. CrossRef Medline

Matsumoto A, Takeishi S, Kanie T, Susaki E, Onoyama I, Tateishi Y, Nakayama K, Nakayama KI (2011) p57 is required for quiescence and maintenance of adult hematopoietic stem cells. Cell Stem Cell 9:262-271. CrossRef Medline

Meijlink F, Beverdam A, Brouwer A, Oosterveen TC, Berge DT (1999) Vertebrate aristaless-related genes. Int J Dev Biol 43:651-663. Medline

Miyagi S, Kato H, Okuda A (2009) Role of SoxB1 transcription factors in development. Cell Mol Life Sci 66:3675-3684. CrossRef Medline

Niwa H (2001) Molecular mechanism to maintain stem cell renewal of ES cells. Cell Struct Funct 26:137-148. CrossRef Medline

Nohno T, Koyama E, Myokai F, Taniguchi S, Ohuchi H, Saito T, Noji S (1993) A chicken homeobox gene related to Drosophila paired is predominantly expressed in the developing limb. Dev Biol 158:254-264. CrossRef Medline 
Norris RA, Scott KK, Moore CS, Stetten G, Brown CR, Jabs EW, Wulfsberg EA, Yu J, Kern MJ (2000) Human PRRX1 and PRRX2 genes: cloning, expression, genomic localization, and exclusion as disease genes for Nager syndrome. Mamm Genome 11:1000-1005. CrossRef Medline

Opstelten DJ, Vogels R, Robert B, Kalkhoven E, Zwartkruis F, de Laaf L, Destrée OH, Deschamps J, Lawson KA, Meijlink F (1991) The mouse homeobox gene, $\mathrm{S} 8$, is expressed during embryogenesis predominantly in mesenchyme. Mech Dev 34:29-41. CrossRef Medline

Pasca di Magliano M, Hebrok M (2003) Hedgehog signalling in cancer formation and maintenance. Nat Rev Cancer 3:903-911. CrossRef Medline

Peterson RE, Hoffman S, Kern MJ (2005) Opposing roles of two isoforms of the Prx1 homeobox gene in chondrogenesis. Dev Dyn 233:811-821. CrossRef Medline

Pevny LH, Nicolis SK (2010) Sox2 roles in neural stem cells. Int J Biochem Cell Biol 42:421-424. CrossRef Medline

Ray J, Gage FH (2006) Differential properties of adult rat and mouse brainderived neural stem/progenitor cells. Mol Cell Neurosci 31:560-573. CrossRef Medline

Ray J, Peterson DA, Schinstine M, Gage FH (1993) Proliferation, differentiation, and long-term culture of primary hippocampal neurons. Proc Natl Acad Sci U S A 90:3602-3606. CrossRef Medline

Scott MP, Tamkun JW, Hartzell GW 3rd (1989) The structure and function of the homeodomain. Biochim Biophys Acta 989:25-48. Medline

Shimozaki K, Zhang CL, Suh H, Denli AM, Evans RM, Gage FH (2012) SRY-box-containing gene 2 regulation of nuclear receptor tailless (Tlx) transcription in adult neural stem cells. J Biol Chem 287:5969-5978. CrossRef Medline

Stecca B, Ruiz i Altaba A (2005) Brain as a paradigm of organ growth: Hedgehog-Gli signaling in neural stem cells and brain tumors. J Neurobiol 64:476-490. CrossRef Medline
Steiner B, Klempin F, Wang L, Kott M, Kettenmann H, Kempermann G (2006) Type-2 cells as link between glial and neuronal lineage in adult hippocampal neurogenesis. Glia 54:805-814. CrossRef Medline

Suh H, Consiglio A, Ray J, Sawai T, D’Amour KA, Gage FH (2007) In vivo fate analysis reveals the multipotent and self-renewal capacities of Sox $2+$ neural stem cells in the adult hippocampus. Cell Stem Cell 1:515-528. CrossRef Medline

Takanaga H, Tsuchida-Straeten N, Nishide K, Watanabe A, Aburatani H, Kondo T (2009) Gli2 is a novel regulator of sox2 expression in telencephalic neuroepithelial cells. Stem Cells 27:165-174. CrossRef Medline

Tanaka S, Kamachi Y, Tanouchi A, Hamada H, Jing N, Kondoh H (2004) Interplay of SOX and POU factors in regulation of the Nestin gene in neural primordial cells. Mol Cell Biol 24:8834-8846. CrossRef Medline

ten Berge D, Brouwer A, Korving J, Reijnen MJ, van Raaij EJ, Verbeek F, Gaffield W, Meijlink F (2001) Prx1 and Prx2 are upstream regulators of sonic hedgehog and control cell proliferation during mandibular arch morphogenesis. Development 128:2929-2938. Medline

Uchikawa M, Kamachi Y, Kondoh H (1999) Two distinct subgroups of Group B Sox genes for transcriptional activators and repressors: their expression during embryonic organogenesis of the chicken. Mech Dev 84:103-120. CrossRef Medline

Zhang CL, Zou Y, Yu RT, Gage FH, Evans RM (2006) Nuclear receptor TLX prevents retinal dystrophy and recruits the corepressor atrophin1. Genes Dev 20:1308-1320. CrossRef Medline

Zhao C, Teng EM, Summers RG Jr, Ming GL, Gage FH (2006) Distinct morphological stages of dentate granule neuron maturation in the adult mouse hippocampus. J Neurosci 26:3-11. CrossRef Medline

Zhao C, Deng W, Gage FH (2008) Mechanisms and functional implications of adult neurogenesis. Cell 132:645-660. CrossRef Medline 